\title{
Bireyve
}

Toplum

\section{Yeni Toplumsal Hareketler ve Gezi Parkı Direnişi}

\author{
Vehbi BAYHAN ${ }^{1}$
}

"Her yer Taksim, her yer direniş"
(moda olan slogan)

Öz: Küresel neoliberalizmin içine girdiği ekonomik kriz, yeni toplumsal hareketlere neden olmaktadır. ABD, İngiltere, İspanya, Yunanistan'da yaşanan eylemler ile Arap Baharı adı verilen isyanlar ve Haziran 2013'teki İstanbul Taksim Gezi Parkı Direnişi yeni toplumsal hareketlere örnek teşkil etmektedir. Yeni toplumsal hareketlerin özünde sosyal ve kültürel kimlik talepleri yer almaktadır. Gazi parkı direnişi, başlangıçta parktaki ağaçların kesilip AVM yapılmasına karşı çevreci bir eylem olarak başlamıştır. Ancak, daha sonra hükümete muhalif bütün legal ve illegal grupların birlikte hükümeti istifaya zorlayan devrim hareketine dönüşmüştür. İstanbul'da başlayan isyan hareketi Türkiye'nin çoğu şehirlerine sıçramıştır. Masum gerekçelerle başlayan Gezi Parkı Direnişi, şiddet eylemleri ile terörize edilmiştir. Gezi Parkı eylemleri şu şekillerde okunabilir: 1. 1980 askeri darbesinden sonra apolitik olarak damgalanan gençlik, Gezi Parkı eylemlerindeki rolleriyle $\mathrm{Y}$ kuşağı olarak kutsanmış ve methiyeler yazılmıştır. 11. Eylemlerin, hükümetin 11 yıldır uyguladığı kalkınma temelli neoliberal uygulamalara bir itiraz olduğu ifade edilmiştir. $\imath \imath$. Direniş, özellikle 11 yıldır iktidarda olan Başbakanı hedef alan ve iktidarı düşürme eylemlerine dönüşmüştür. $\mathfrak{w}$. Başbakan, eylemleri Türkiye'nin kalkınmasını istemeyen

1 Yrd. Doç. Dr., İnönü Üniversitesi Sosyoloji Bölümü, vehbi.bayhan@inonu.edu.tr 
dış ve iç güçlerin organize ettiği komplo teorisiyle okumuştur. $v$. Sosyalist ideolojiye sahip olanlar Gezi Parkıdirenişini “Taksim Komünü” olarak adlandırarak heyecanlanmışlardır. vı. Arap Baharı isyanlarında olduğu gibi Gezi Parkı eylemlerinde de sosyal medya ve internet temel iletişim aracı olmuştur. Tıpkı 1968 yılındaki gençlik eylemleri gibi Haziran 2013’de yaşanan Gezi Parkı Direnişi de diğer ülkelerdeki toplumsal hareketlerin taklididir. Nasıl 68 eylemleri romantik idiyse, 2013 Gezi Parkı eylemleri de romantiktir. Bu bağlamda, isyan bulaşıcıdır. Ancak, romantik de olsa Gezi Parkı direnişi, seçimle düşürülemeyen iktidara karşı olanların kin ve nefretlerinin dişa vurumudur. Bu durum toplumda zımni olan "biz" ve “öteki” ayrımlaşmasını gün yüzüne çıkarmıştır. Bu durum da, birbirine güvenmeyen ve kuşkuyla yaklaşan "Paranoid-Şizoid Toplum” yapısını üretmektedir.

Anahtar Kelimeler: Yeni toplumsal hareketler, Gezi Parkı direnişi, neoliberalizmin krizi, Paranoid-Şizoid Toplum.

\section{Giriş}

Enformasyon toplumu, risk toplumu, gözetim toplumu, ağ toplumu vb. kavramlarla ifade edilen 21. Yüzyılın postmodern zamanlarında "yeni toplumsal hareketler” özellikle gençlerin başrolde bulunduğu tepki hareketleri olarak dünyanın farklı ülkelerinde yaşanmaktadır. Küresel ekonomik krize bir tepki olarak ABD'de Wall Street eylemleri, Londra'da üniversite gençliğinin öğrenim harçlarının arttırılmasına karşı gösterileri, yine 2011 Ağustos ayında Londra'da başlayan ve diğer İngiliz kentlerine de sıçrayan yağma ve isyanlar, Atina' da ve Madrid'te yaşanan gençlik eylemleri, Tunus'ta başlayıp, Libya ve Mısır'da devam eden "Arap Baharı” ile 31 Mayıs 2013’te İstanbul'da başlayan ve 18 gün süren Gezi Parkı eylemleri "yeni toplumsal hareketler" bağlamında analiz edilebilir.

Sosyal olaylar çok girifttir, tek boyutlu ve tek nedenli olarak meydana gelmezler. Sosyolojik muhayyele, sosyal olayları bütün boyutlarıyla ve çok nedenli olarak analiz etmek anlamına gelmektedir. Bunu 
yapmak için de diyalektik düşünme yöntemi, yani "tez-antitez-sentez süreci” ile olayları irdelemek gerekmektedir. Sosyolojik muhayyele de karşı söylemleri anlamak için empatik düşünmek önem taşımaktadır. Ancak, empatik düşünme süreci için emek harcamak gerekir. Çünkü, herkes kendi toplumsal ve kültürel bağlamında kimliğini oluşturduğu ve sosyalleşme sürecinde hazır reçetelerle ontolojik mevcudiyetini inşa ettiği için "kendi doğruları" ile yaşamak onları mutlu eder. Yine herkes, kendi "cemaatinde" (sosyolojik anlamda cemaat; ideolojik, dinsel, etnik, sosyal vb.) varlı̆̆ını anlamlandırır ve "aidiyet psikolojisi” ile tatmin olur. Bu çerçevede, "biz” ve "öteki” olarak kurgulanan ve kurulan toplumsal yapıda farklı grupların birbirini anlamaları için çaba sarfetmeleri kolay olmamaktadır. Herkes kendi gettosunda mesuttur. Bu gerçeklik normal süje (özne) için bir vakıa olsa da, sosyolojik analiz yapan bilim adamının kendi bağlılık ve prangalarından kurtulması ve empatik düşünmesi "olması gerekendir". Pozitivist paradigmanın iddiasında olduğu gibi bilim adamının "pür objektif” olması ne kadar tam anlamıla mümkün olmasa da, hermeneutikparadigma söylemindeki "pür görecelik" ve "anythinggoes" (ne olsa gider) savı da "anomi" (normsuzluk) üretme ihtimaline sahiptir. Sosyal bilimlerde gelinen son nokta hem pozitivist hem de hermeneutikparadigmanın bir sentezidir.

Toplumsal hareketler de sosyolojik muhayyele ile empatik düşünce ile irdelenmelidir. Tarih, sosyolojinin laboratuvarıdır. Sosyal olayların olabildiğince objektif irdelenmesi için belirli bir sürenin geçmesi gerekmektedir. Nasıl ki 1968 gençlik eylemleri ancak 20 yıl sonra geniş perspektifle analiz edilmişse, 2013 Haziran ayında yaşanan Gezi direnişinin objektif analizi için zamana ihtiyaç vardır. Ancak, Gezi eylemlerini sosyolojik muhayyele ile bütün boyutları ve farklı söylemler bağlamında irdelemek mümkündür. Her ne kadar "biz" ve "öteki” gruplaşması çerçevesinde, eylemi ve eylemcileri öven yaklaşımların demokratik, direniş ve direnişleri eleştiren yaklaşımların otokratik olarak "damgalandı̆̆ı" bir toplumsal bağlamımız varsa da,(ki bu bağlam 11 Eylül 2001 küresel terör eylemlerinden sonra ABD başkanı Bush'un “ya bizdensiniz” ya da "onlardan" söyleminde ifadesini bulan kutuplaştırıcı politikayla aynıdır) bu durumu "sivil dikkatsizlik" ile önemsemeyerek, bu makalede 
sosyolojik muhayyele ile eleştirel bir paradigmadan ve yeni toplumsal hareketler sosyolojisi açısından Gezi parkı direnişi değerlendirilmeye çalışılacaktır. Sosyoloğun son tahlilde sosyal ve kültürel bir süje olarak kendi benliğinde aidiyetlikleri olsa da, araştırma yaparken prangalarını askıya asması ve olabildiğince objektif olması temel çıkış noktasıdır. Tarafgir olmak kolaydır. Önemli olan olabildiğince tarafsız olmaktır.

\section{Yeni Toplumsal Hareketlerin Sosyolojik Bağlamı}

Sosyal hareketler literatüründe kabul gören ortak tanıma göre toplumsal hareketler; birbirleriyle dayanışan, ortak bir fikri ve duyguyu paylaşan, haksızlık veya eşitsizlik olarak gördükleri bir meseleyi çözmek için seferber olup sorunlarının kaynağı olarak belirledikleri aktör ve/ veya kurumlara yöneltilmiş protestolar düzenleyen, süreklilik kazanmış enformel toplumsal ağlardır (Alpuncu, 2013). Sosyal hareketlerin temelinde Gustave Le Bon'un "Kalabalık Psikolojisi” teorisi yer almaktadır.

Modernliğin ilk dönemlerindeki hâkim hareketler ekonomik çıkarlar üzerinde yoğunlaşmış, genelde tek bir sosyal sınıftan oluşan üyeleriyle siyasal gücü ele geçirmek için merkezi bir şekilde örgütlenmişlerdi. Devrim fikriyle özdeşleşmiş ve neredeyse bir siyasal partinin ya da siyasal hareketin gölgesinde şekillenen işçi hareketi bu tip hareketlerin en iyi örneklerinden biridir. Bu hareketin içindeki işçiler, birer aktörden ziyade tarihsel bir zorunluluğu yerine getirmek için mücadele eden figürlerdir. Bu tip hareketler eski (sanayi) toplum tipine ait olduklarını ima etme anlamında "eski sosyal hareketler" olarak adlandırılır. Eskileri gibi yeni sosyal hareketler de ortaya çıtıkları toplum bağlamından bağımsız değildir (Çayır, 1999:16). Yaşanılan hızlı değişim ve dönüşüm, sosyal hareketlerin türü ve niteliğini değiştirmiştir. Hareketin aktörleri, amacı, uygulama şekli, süresi ve etki alanı yeni bir boyut kazanmıştır. Yeni olarak nitelendirilen bu sosyal hareketler, değişimden ziyade, rahatsız olunan bir konuya dikkat çekmeyi amaçlamaktadır (Şentürk, 2006: 31).

Yeni toplumsal hareketlerle ilgili en popüler sinıflandırmalardan biri, Amerikan menşeyli “Kaynak Mobilizasyonu Paradigması”, diğeri 
ise Avrupa menşeyli "Yeni Sosyal Hareketler Paradigmasıdır". Kaynak mobilizasyonuparadigması, toplumsal hareketlerin ekonomik ve politik yönü üzerinde dururken; yeni sosyal hareketler paradigması, hareketlerin kültürel yönü üzerinde durmaktadır (Gürakar, 2014: 237).

Hardt ve Negri'ye göre, günümüzün toplumsal hareketleri düzeni tersine çeviriyor, manifestoları ve peygamberleri gereksiz kılıyor. Değişimin failleri şimdiden sokaklara indiler ve şehir meydanlarını işgal ediyorlar; yalnızca yöneticileri tehdit edip alaşağı etmekle kalmıyor aynı zamanda yeni bir dünya vizyonu oluşturuyorlar. Belki daha da önemlisi, mantıkları ve pratikleri, sloganları ve arzularıyla, bu çokluklar yeni bir dizi ilke ve hakikatin duyurusunda bulunuyorlar (Hardt ve Negri, 2012: 7-8).

Touraine ve Melucci'nin önderliğini yaptığı yeni toplumsal hareketler paradigması mevcut değerler, normlar ve kimlik yapılarında değişim taleplerini simgeleyen sosyo-kültürel boyutu öne çıkarmaktadırlar (Çayır, 1999: 23). Touraine’e göre toplumsal hareketler, politik düzeyi aşarak tarihsellik düzeyinde yeni bir toplumun kendini üretme kapasitesi işlediğini öne süren sivil toplumdur. Toplumsal hareketler, "bir toplumsal duruma tepki değil, kültürel modeller ve tarihsellik üzerinde kontrol için savaşan bireyler arasındaki çatışmanın bir sonucu olarak ortaya çıkmaktadır. Bu çatışma, siyasal sistemin kırılmasına ya da kültürel reformlara yol açabilir. Bir sosyal hareket kendisi aracılığıyla kültürel yönelimlerin tarihsellik alanının bir toplumsal örgütlenme biçimine dönüştürüldüğü çatışma davranışıdır” (Touraine, 1999: 49-50). Bu bağlamda Touraine toplumsal hareketi şöyle tanımlamaktadır: "Bir sosyal hareket, tarihselliğin biçimi, kültürel yatırım, bilgi ve ahlak modelleri üzerindeki hakimiyeti ya da bağımlılığı ile tanımlanan bir sosyal sınıfın, bu kültürel modellere yönelmiş çatışmacı hareketidir” (Touraine, 1999: 51). Melucci'ye göre, son dönemlerde ortaya çıkan kolektif hareketler, yaş, cinsiyet farklılıkları, sağlık, tabiatla ilişki ve insan neslinin devamı gibi daha önce gündeme gelmemiş sosyal çelişkilerden kaynaklanmakta ve sosyolojik analizde önem kazanmaktadır (Melucci, 1999: 81). Çevrecilik, etnisite, cinsel kimlik, barış gibi temalar etrafında 
örgütlenen gruplar, toplumsal sahnenin yeni aktörleri olarak ortaya çımaktadır. Küreselleşmeye paralel olarak ortaya çıkan yeni hareketlerin / kimliklerin ve hayat tarzlarının oluşum süreci yeni toplumsal hareketlerin merkezinde yer almaktadır (Çayır, 1999:32). İnsanlar sadece ekonomik endişelerinden değil, yaşam kalitesi sorunu ile de motive edilen toplumsal hareketlere katılmaktadırlar. Hareketlilik ulusal veya uluslararası alandadır. Yeni toplumsal hareketler, kitle iletişim araçları ve yeni bilgi teknolojilerinin genişlemesine koşut olarak ortaya çıkmaktadır (Macionis, 2012: 617).

Touraine'e göre post endüstriyel toplum, daha önceki dönemden ekonomik, siyasal ve toplumsal anlamda farklı ilişkilerin görüldüğü bir toplum tipidir. Bu dönemde siyaset değişmiştir, ekonomi değişmiştir ve buna bağlı olarak da toplumsal ilişkiler değişmiştir. Bu değişen koşullar içinde mücadele eden toplumsal hareketler, yeni döneme uyum sağlama açısından farklı örgütlenme ve mücadele yolları benimsemişlerdir. Bu hareketleri de "yeni” yapan ortaya çıktıkları koşullar içinde farklı bir örgütlenme ve işleyiş mekanizması oluşturmalarıdır. Yeni sosyal hareketlerin ortaya çıkışı sosyal hareketler ve siyasal yapı arasındaki dönüşümü simgelemektedir. Yeni toplumsal hareketler, yaşanan dönüşüm sonucu sivil alan içerisinde siyasal erk talebi olmayan ve devleti kontrol etme amacı olmayan bir yapılanma ortaya koydukları için yenidir (Çayır, 1999: 16).Yeni sosyal hareketler, liderlik anlayışı ve bir kahraman önderliğinde birleşme yerine, gönüllülük esası ile süreçte eşit yönetim hakkına sahip aktivist birliktelikleri olarak ortaya çıkmıştır (Çopuroğlu ve Çetin, 2010: 73). Yeni toplumsal hareketler, geleneksel işçi ve sınıf mücadelelerinin gitgide dışına kayan, sosyo-ekonomik taleplerden ziyade yerel, kültürel, kimliksel ve yaşam tarzıyla ilgili konulara odaklanan, devleti ele geçirmekten ziyade ona karşı özerk sivil alanların üretim ve / veya yeniden üretiminde direten, kimi durumlarda farklı amaç ve çıkarların birbirine eklemlendiği gevşek biraradalıkları ihtiva eden, özünde parçalı, merkezsiz ya da silik merkezli bir hüviyet kazanmıştır (Gürakar, 2014: 236-237).

1999'da “Seattle Muharebesi” ile başlayan küreselleşme karşıtı eylemler, Yeni Toplumsal Hareketler açısından önemli eylemlerdir. Ulusal 
ve uluslararası iletişim ağları aracılığıyla örgütlenen bu hareketler somut bir soruna odaklanmaktadır. Merkezsiz, örgütsüz ve ideolojisiz olduğu için kendiliğinden bir eylem şeklinde gelişmektedir. Neoliberal politikalara karşı başlayan bu yeni eylem biçimi, aynı kalıplarda occupy (İşgal et) eylemlerinde, renkli devrimlerde ve Arap Baharı'nda görüldü. $\mathrm{Bu}$ hareketlerin kendi aralarında bir amaç birliği yok; sadece kullandıkları teknikler ve taktikler örtüşmektedir. İki ortak paydadan ilki, rahat iletişim imkânına sahip ileri toplumlarda veya toplumun üst tabakalarında ortaya çıkması. Başlangıçta Kuzey Amerika'da “zengin beyazların iyi kalpli eylemleri” olarak gelişen bu eylemler henüz orta sınıfın altına inebilmiş değiller. İkinci ortak payda ise geniş kitlelerin "karşıtlık" ekseninde bir araya gelmesi. İnsanlar bir şeylere karşı oldukları için bir araya gelmekte ve karşı oldukları şeyi birlikte protesto etmektedir.Bu hareketler, bir siyasî örgüte dönüştügüu, bürokratik karar mekanizmalarına bağlandığı zaman buharlaşıp yok olmaktadır.Duygu, rasyonel araçlardan ve amaçlardan daha etkili olmaktadır. Toplumsal hareketin ömrünü bu duygu birliği tayin etmektedir. Korku, acı, kızgınlık, intikam duygusu, öfke, incinme ve kendini ifade sıkıntısı ana motivasyonu sağlamaktadır. Bu yüzden eylemler Gezi Parkı’nda olduğu gibi şölen, konser, sanat performansı üzerinden bir araya gelerek, çok farklı insanlara kişiliğini kaybetmeden içinde eriyeceği duygusal ortamlar sağlamaktadır (Türköne, 2013).Duyguların birlikteliği toplum mühendisliği açısından kitleleri yönlendirmekte önemli unsurdur. Bu bağlamda, duyguların iletişimi, Mevlana’nın "Aynı dili konuşanlar değil, aynı duyguları paylaşanlar anlaşabilir” sözünde anlamını bulmaktadır. Gezi eylemlerinde de farklı siyasi görüşlere sahip olsalar da iktidara karşı olmak, nefret ve öfke duygularının ortaklığı kitlelerin bir araya gelmesinde sinerji yaratmıştır.

Toplumsal hareketlerin çoğunlukla kültürel bir çatışma bağlamında ortaya çıktığı söylenebilir. Bunlar; kişinin kendi hayat tarzına sahip olma hakkı, farklı olma hakkı, yeni tür risklere karşı bireysel korunma hakkı gibi. Bu açıdan değerlendirildiğinde yenitoplumsal hareketler tarafından açıkça belirtilen iddialar, hem savunma amaçlı (tepkisel) hem de önleyici (proaktif)dir. Aynı zamanda kamusal alanı insanileştirmek 
ve demokratikleştirmek için de topluca çalışmaktadırlar. Hem hücuma hem de savunmaya yönelik açıklama arasındaki denge, devamlı değişmekte ve bu açıklamalardan birine olan vurgu, hareket gelişirken konjonktürel durumlara bağlı olarak değişebilmektedir (Hannigan 2012: 255'den aktaran: Işı1k, 2013:20). Yeni toplumsal hareketlerin kültürel temelli olması, Bourdieu'nun “toplumsal alanlar teorisi" bağlamında da okunabilir. Toplumsal yapıdaki ekonomik sermaye, iktisadi kaynakları ifade etmekte; kültürel sermaye, eğitim sürecinde ve aileden elde edilen entelektüel niteliklerin bütününü içermekte; toplumsal sermaye, birey veya grubun kalıcı ilişkiler ağına ve kurumsallaşmış karşılıklı tanıma ve tanımlamayla elde edilen gerçek veya potansiyel kaynakların toplamına tekabül etmekte; simgesel sermaye ise, onura, tanınmaya ve kabule dayalı alg1 kategorisini betimlemektedir.Bu sermayelerin farklı kompozisyonu ve alanların işleyişinde Bourdieu’nun "habitus" kavramı önem taşımaktadır. Habitus, toplumsallaşmış bir öznelliği ifade etmekte, ancak uyaranlara ve alanın yapısına göre zıt pratikleri de ortaya çıkartabilmektedir. Bir yandan alan, habitusu yapılandırırken, diğer yandan da habitus, alanın yeniden üretilmesine katkıda bulunmaktadır (Gürakar, 2014: 239-240). Habitus, yapı ve fail arasındaki etkileşim sonucu oluşan ve somutlaşan ideal tipleri oluşturmaktadır.

Bourdieu'nun "toplumsal alanlar teorisinden" mülhem Gezi eylemleri "çapulcular alanı" olarak tanımlanabilir. Çapulcu kavramı, eylemlerde bulunanlara atfen başbakan tarafından ifade edilmiş, eylemciler de bu kavramı mizah süzgecinden geçirerek ve yeni anlamlar yükleyerek kendilerini ifade etmenin simgesi haline dönüştürülmüştür. Çapulcular alanı; yapısı ve bileşenleri itibariyle direnişçilerin farklı sınıfsal konumlarının ve habituslarının etrafında şekillendiği, özünde birbirinden farklı özgül çıkarları ihtiva eden, farklı oyunların iç içe geçerek iktidar alanına karşı birarada oynandığı ancak dinamizmi sayesinde sürekli başkalaşıma uğrayarak yeni öznelliklerin de üretildiği sinerjik bir direniş pratiği yaratmıştır (Gürakar, 2014: 243). Bu çerçevede, önce benzer habitusa sahip öznelerin başlattığ 1 eylemlere daha sonra farklı habituslara mensup öznelerin katılımıyla çapulcular alanı postmodernizmin özündeki "çoğulcu” bir kimlik kolajı imgesi vermiştir. Ancak, 
bu çoğulculuk iktidara "karşı” olmak temelinde oluşan "günü kurtarmaya" yönelik birliktelik imgesidir.

Eylemcilerin çapulcular alanı içerisindeki konumları incelendiğinde, direnişin çekirdeğini; sahip oldukları ekonomik ve kültürel sermayelerinin bütünü açısından toplumun orta sınıfına mensup, kentli, ebeveynleri tarafından daha iyi bir refah seviyesinde yaşayacakları umudu içinde egemen tüketim kalıplarına uygun olarak yetiştirilmiş, yüksek eğitimli, evrensel değerleri savunan, dolayısıyla da başbakanın şahsıyla özdeşleşmiş "buyrukçu” siyaset imgelerinden rahatsız olan birçoğu öğrenci ve beyaz yakalı genç kuşak ücretliler ile sanatçılar, mimarlar ve şehir planlamacıları gibi profesyoneller ve bunların mensubu oldukları dernekler, meslek odaları ve benzeri platformlar teşkil etmiştir. Ayrıca direniş sürecinde kolluk güçlerinin "orantısız güç kullanımı" karşısında, onları yermek amacıyla ürettikleri mizahın "orantısız zeka kullanımı" adıyla sosyal medyada bulduğu yorum, bu kesimlerin sahip oldukları kültürel sermayenin önemli bir simgesel göstergesidir. Bu çerçevede, sosyal medyada kullandıkları söylemlerden bazıları şunlardır: "Tüp kaçağını yakarak kontrol eden bir milleti biber gazıyla korkutamazsınız!”, "Bu biber gazı bir harika dostum!", “Tomayla 8 gündür beraberiz, ciddi düşünüyoruz!!” (Gürakar, 2014: 243). Bu durum, 1980 askeri darbesinden sonra apolitik olarak nitelendirilen gençliğin bu eylemlerdeki performansı dolayımında Y veya milenyum kuşağı gençliği olarak kutsanmıştır.

Çekirdek grubun bir sonraki halkasında, kendilerini siyasi yelpazenin solunda tanımlayan irili ufaklı her türlü fraksiyondan siyasi partiler, gençlik platformları ve örgütler ile bunların seçmeni ve / veya sempatizanı kitleler eklemlenmektedir. En son halkada ise direnişe doğrudan katılmamakla birlikte farklı sınıfsal konumlara sahip, dolayısıyla da farklı siyasal, ekonomik ve toplumsal beklentiler içinde olan, hükümete kızgın kimseler bulunmaktadır. Dolayısıyla, direnişçilerin türdeş olmayan sınıfsal, siyasal ve kültürel komposizyonu ve bunun beraberinde getirdiği farklı talep ve söylemleri, bu analizin yalnızca iktisadi çelişkilerle gerekçelendirilemeyeceği gerçeğini gün yüzüne çıkartmıştır 
(Gürakar, 2014: 249-250). Bu realite, gezi direnişinin yeni toplumsal hareketler sosyolojisi bağlamında okunmasınıgerekli kılmaktadır.

\section{Yeni Toplumsal Hareketler Bağlamında}

\section{Gezi Parkı Eylemlerini Okumak}

Gezi Parkı direnişi, toplumsal hareketler paradigmaları çerçevesinde şu şekilde analiz edilebilir.

1. Göreceli Mahrumiyet Teorisi: İkinci Dünya Savaşı̉ndan sonra ortaya çıkmıştır. Sokak protestolarına katılan grupların bazı haklardan mahrum edildikleri için şikayetçi ve kızgın olduklarını savunur. İçinde bulundukları ortamda kendi durumlarını diğerleri ile kıyaslayan gruplar çoğunlukla maddi şartlar açısından bazen de haklar açısından s1kıntı çekiyorlarsa protestolara katılma eğiliminde olurlar. Ancak, Gezi protestolarına katılanlar orta ve üst sosyal sınıfa mensup ve yoksulluk derdi ile fazla ilgilenmemişlerdir. Dolayısıyla, maddi nedenlerden daha çok ideolojik nedenlerle Gezi eylemlerine katıldıkları verileri, Gezi Parkı direnişinin göreceli mahrumiyet teorisine uymadı̆̆ını göstermektedir (Uysal, 2013:30). Gezi Parkı eylemlerini çevre duyarlılığ 1 ile ilk başlatan çekirdek grubun akademisyen ve entelektüel olmaları, parkta karnaval havasında eyleme katılan gençlerin vakıf üniversiteleri ve kolejlerden gelen / getirilen ve çoğunluğu varsıl ailelere sahip oldukları düşünülürse; eylemlerin sorunsalının ekonomik olmadığı somutlaşmaktadır.

2. Kaynak Mobilizasyonu (Hareketliliği) Teorisi: Sosyal alanı, ekonomik açıdan arz-talep meselesi olarak analiz etmektedir. Bu teori, kızginlıkların her zaman var olduğunu, protesto ve toplumsal hareketlere katılımın esas itibariyle kaynakları harekete geçirme ve kaynakların rasyonel bir şekilde kullanılmasına bağlı olduğunu iddia etmektedir. Gezi olaylarında medya, sosyal medya, para, bilgi ve beceri, sosyal sermaye ve lojistik destek açısından farklı kaynakların harekete geçirilmesi açısından, kaynak mobilizasyonu teorisini içermektedir (Uysal, 2013: 3031). Diğer bakımdan Gezi eylemlerinin, 11 yıllık iktidarı düşürmek için bir eyleme dönüşmesinin altında, ekonomik kaynakların (ihalelerin) iktidar tarafından kendine yakın işadamlarına dağıtması zımni olsa da 
bulunmaktadır. Bu bağlamda, Gezi eylemlerinde TUSİAD üyesi işadamlarının aktif rol alması bu durumla ilgilidir.

3. Yeni Toplumsal Hareketler Teorisi: Avrupa kaynaklı yeni toplumsal hareketler teorisine göre, hareketler çevre ve savaş karşıtlı̆̆ gibi öncelikle maddi çıkar içermemekte, daha çok belirli bir yaşam tarzının sürdürülmesi üzerine yoğunlaşmaktadır. Gezi eylemleri, maddi çıkardan daha çok yaşam tarzının sürdürülmesi üzerine yoğunlaştığı için yeni toplumsal hareketler teorisine daha çok uymaktadır. Gösterilere medyatik isimlerin destek vermesi ile bir fedakârlıktan daha çok bir kutlama ve eğlence havasına sokulması katılımı artırmıştır (Uysal, 2013: 31). Gezi direnişi başlangıçta çevre duyarlılığı, kalkınma ve tüketim temelli neoliberal uygulamalara tepki olarak başlamıştır. Ancak, daha sonra salt hükümete karşıt olanların birleştiği ve şiddet eylemlerine dönüşen isyana evrilmiştir. Ayrıca, tüketimciliği eleştiren ilk grup eylemcilerin üst sosyal sınıf hayat tarzına bakıldığında, varsıllıklarıyla en fazla lüks ve marka tüketimi yaptıkları bir vakadır. Bu gerçeklik, sloganlar ve eylemin nedeni ile reel hayat arasındaki paradoksu yansıtmaktadır. Bu durum, şizofren bir parçalı kimlik üretme riskini barındırmaktadır. Yine eylemlere katılan ve Y kuşağı olarak nitelendirilen çoğunluğu özel vakıf üniversiteleri ve kolej öğrencilerinin, Gezi parkı direnişine arkadaşlarının "mahalle baskısıyla" ve kitle psikolojisiyle gittikleri de bir vakıadır.

4. Söylem (Framing) Teorisi: ABD kaynaklı söylem teorisi, durumlarının iyi veya kötü olmasından daha çok toplumda bir sorun bulunduğu konusunda sosyal grupların ikna edilmeleri gerektiğine işaret eder.Söylemlerin öncelikle bir problemin varlığına ikna etmesi gerekmektedir. Gezi olayları için bir yandan ağaçların kesilmesi, diğer yandan da laik yaşam tarzına müdahale olduğu yönünde problem tanımlaması başarıyla yapılabilmiştir. Eylemin sonuç almasının mümkün olacağı konusunda katılımcıların ikna edilmesi için medya ve sosyal medya kullanılmıştır. Söylemlerin toplumun kültüründe yankı bulması için ağaç ve çevre sevgisi ciddi bir sempati uyandırmıştır. Polis şiddetinin aşırı gösterilmesi de bir mağduriyet yaratarak toplumda geniş yankı bulmuşsa da, gösterilerin giderek daha radikal grupların kontrolüne girmesi, çözüm 
konusunda kendi aralarında görüş ayrıllğ̆ olması ve Hükümet'in diyalog yoluyla uzlaşma çalışmaları ılımlı grupları meydandan uzaklaştırmıştır. Meydan'da kalan radikal gruplar ise kolayca dağıtılmıştır (Uysal, 2013: 31-32). Medyatik ünlülerin medya ve sosyal medyadaki propagandaları "siyasi mühendisliğin" bir boyutunu oluşturmuştur. Kitle psikolojisini yönetmek siyaset sosyolojisi ve psikolojisinin uygulama alanıdır. Bunun için her yol mubahtır.

Yeni toplumsal hareketler paradigmaları bağlamında Gezi eylemlerinin irdelenmesi, sosyolojik açıdan toplumun sosyal ve kültürel yapısını analiz ile daha net okunabilir. Yeni veya postmodern toplumsal hareketler, toplumsal ve kültürel yapının bir ürünüdür. Postmodern toplumsal yapının temel sistemi neo-liberal ekonomi politiktir. Küresel neo-liberal sistemin toplumsal yapidaki etkileri postmodern toplumsal hareketleri oluşturan temel saiktir. Bu bağlamda, Hardt ve Negri’nin (2012), analizlerine göre, neoliberalizmin zaferi ve krizi ekonomik ve politik hayatın koşullarını değiştirdi ancak aynı zamanda da, yeni “öznellik figürleri” oluşturarak, toplumsal, antropolojik bir dönüşümü başlattı. Hardt ve Negri krizin bu öznel figürlerini 4'e ayırmaktadır: "borçlandırılanlar, medyalaştırılanlar, güvenlikleștirilenler ve temsil edilenler”.

1. Borçlandırılanlar: Finansın ve bankaların egemenliği borçlandırılanları yarattı. Borçlu olmak günümüzde toplumsal yaşamın genel koşulu haline geliyor. Borca girmeden yaşamak neredeyse imkânsız: öğrenciler burs alıyor, ev için uzun vadeli kredi, araba için kredi, doktor reçetesi için ise borç alınıyor ve liste böyle uzayıp gidiyor. Öznelliğimiz artık borç temelinde şekilleniyor. Borç alarak hayatta kalıyorsunuz ve bu borçlar karşısındaki sorumluluğunuzun ağırlığı altında hayatınızı sürdürüyorsunuz. Borç sizi kontrol ediyor. Borç tüketimimizi disipline sokuyor, sizi kemer sıkmaya zorluyor ve sıklıkla sizi hayatta kalma stratejilerine geriletiyor ama bunun ötesinde borç size çalışma ritmi ve birtakım tercihler dayatıyor. Eğer üniversiteyi borçlu bitirmişseniz, borcunuzu ödemek için size önerilen ilk ücretli işi kabul etmek zorunda kalıyorsunuz. Eğer uzun vadeli kredi alarak bir daire edinmişseniz, işinizi kaybetme, bir tatile çıkma veya kendinizi geliştirmeye 
zaman ayırma lüksünüz olmuyor. Siz borçlarınızdan sorumlu olursunuz ve hayatınızda yarattığı zorluklardan dolayı suçluluk duyarsınız. Borçlandırılan, suçluluğu yaşam biçimine dönüştüren mutsuz bir bilinçtir. Sömürü bugün asıl olarak mübadele değil borç temeline, yani nüfusun yüzde 99'unun yüzde l'e tabi oluşuna -iş borçlu, para borçlu, itaat borçlu oluşuna- dayanıyor. Yeni bir yoksul figürü doğuyor ve bu yalnızca işsizler ve düzensiz, güvensiz, güvencesiz ve yarım gün çal1şanlardan oluşmuyor. Aynı zamanda, düzenli çalışan ücretlileri ve orta sınıfın yoksullaşan kesimini de kapsıyor. Onların yoksullukları asıl olarak borç zincirlerine dayanıyor. Esaret ilişkisi tekrar üretiliyor (Hardt ve Negri, 2012: 18-21). Bankaların sorumsuzca dağıttığı kredi kartlarıyla, tüketim tapınakları AVM'lerde alış veriş yaptığında mutlu olan / olduğunu zanneden, ancak geliri kredi kartı borcunu ödemeye yetmeyince, başka bankanın kredi kartından para çekerek borcunu ödeyen ve sürekli bir borç sarmalında yaşamaya alıştırılmış "postmodern esir" bireyler (Bayhan, 2012:164).

2. Medyalaştırılanlar: Bilişim ve iletişim şebekeleri üzerindeki kontrol medyalaştırılanları yarattı. Günümüzün medyalaştırılan özneleri enformasyon, iletişim ve ifade fazlalığından muzdarip olmaktadır. Özellikle egemen ülkelerdeki birçok işçi için, sosyal medya onları aynı zamanda hem işlerinden özgür kılıyor hem de işlerine zincirliyor. Akıllı telefonunuz ve kablosuz bağlantınızla, her yere gidebiliyorken aynı zamanda da işinizin başında kalabiliyorsunuz. Yani, nereye giderseniz gidin yine de çalışıyorsunuz! Medyalaştırılma, iş ile yaşam arasındaki ayrımın giderek belirsizleşmesinde ana etkendir. Bu yüzden, böylesi işçilerin yabancılaşmasından değil medyalaştırılmasından söz etmek daha doğrudur. Yabancılaşmış işçinin bilinci ayrılmış veya bölünmüşken, medyalaştırılan iş̧̧inin bilinci ağ ortamına tabi kılınmış veya özümsenmiştir. Medyalaştırılanın bilinci gerçekte yarılmamış, parçalanmış ve dağılmıştır. Medyalaştırılanın öznelliği bu yüzden paradoksal olarak ne aktif ne de pasiftir, sürekli olarak dikkat kesilmiş bir halde bekler. Nasıl ki insan üretkenliği borçlandırılan figüründe maskelenmişse, aynı şekilde medyalaştırılan figür de gizemleştirilen ve içi boşaltılmış insan zekâsı barındırmaktadır. Medya, her geçen gün hayatımızın daha derinlerine 
işlemektedir. Hayat deneyimlerimizin, özlem ve arzularımızın karmaşı anlatıları yerini sosyal medyadaki tipik sorulara bıraktı: Şimdi neredesin? Ne yapıyorsun? Dostluk alışkanlıkları ve pratikleri "online arkadaşlık” işlemlerine indirgendi (Hardt ve Negri, 2012: 22-25). Gençler, sürekli cep telefonlarından veya sosyal medyadan gelen mesajları izleme ihtiyacındadır. Facebookta kendilerinin ne kadar takipçisi olduğu ve kendi sayfalarında paylaştıklarına ne kadar "like" (beğeni) aldıkları çerçevesinde "narsisist" kimliklerini tatmin ederler. Herkes İnstagram, Youtube, Twitter ve Facebookda “microcelebrity” (küçük şöhret) olmayı hedeflemektedir. İnternet bağımlılığı, sosyal medyadaki paylaşımları beğenme, cep telefonunun titreşimini, eposta ve mesajların sürekli kontrolü sendromu sonucunda gençlerde yaratıcılık ve empati düzeyleri düşmektedir (Stein ve Sanburn, 2013). Bütün mahremiyetini sosyal medya ile paylaşan, hem "teşhirci" hem de "röntgenci" konuma gelen "sanal nettaşlar" "pornografik" bir gösterinin özne ve nesneleri olarak "mahremiyetlerini tüketmektedir” (Bayhan, 2012:165).

3. Güvenlikleştirilenler: Güvenlik rejimi ve genelleştirilen istisnalar devleti korkunun pençesine düşmüş ve korunmak için yalvaran bir figürü, güvenlikleştirilenleri yarattı. Havaalanı güvenliğinden geçerken bedeniniz ve eşyalarınız cihazlarla taranıyor. Belli ülkelere girerken parmak izi veriyorsunuz, göz retinanız taranıyor, işsiz kalıp sosyal güvenlik yardımı almaya başlayacak olursanız, farklı türden bir denetim zincirine tabi tutuluyorsunuz; çabalarınız, niyetleriniz ve gösterdiğiniz gelişmeler kayıt altına alınıyor. Hastane, hükümet dairesi, okul; hepsinin kendi denetleme rejimi ve veri toplama sistemi mevcuttur. Ancak bütün bunlar başınıza yalnızca özel bir yere girdiğinizde gelmez. Sokakta yürüyüşünüz de büyük bir ihtimalle bir dizi güvenlik kamerası tarafından kaydedilmekte, kredi kartı harcamalarınız ve İnternette yaptığınız aramalar takip edilmekte, cep telefonu aramalarınız kolaylıkla dinlemeye takılmaktadır. Güvenlik teknolojileri yakın tarihte büyük bir sıçrama yaparak toplumun, hayatımızın ve hatta bedenlerimizin derinlerine nüfuz etti. Bir hapishane toplumunda yaşamayı kabul edersiniz çünkü dışarısı size daha tehlikeli görünür. 
İnsan güvenliğin nesnesi değil aynı zamanda öznesidir de. Gözünüzü dört açın çağrısına yanıt verirsiniz; metroda sürekli kuşkulu davranışları gözlersiniz; uçakta yanınızda oturan adamın şeytani planları olduğunu, komşunuzun kötü niyetler beslediğini düşünürsünüz. Korku, görünüşte evrensel güvenlik aygıtına gözlerinizin gönüllü hizmet vermesinin ve kulaklarınızın sürekli tetikte oluşunun haklılık gerekçesidir. Güvenlikleştirilen toplumda hem mahpus hem de gardiyan rolünü oynarsınız (Hardt ve Negri, 2012: 26-27). Bu durum, bireyin kişiliğinde şizofrenik parçalanmalara neden olma riskini taşımaktadır. Postmodern birey "hem o hem de o" olmanın getirdiği kaosu yaşamaktadır.

Güvenlik rejiminin gözetim, denetleme ve fişleme biçimleri aslında Marx’ın kapitalizm öncesi İngiltere'sinde mülksüz ve aylak sınıflara yönelik "kanlı yasalar"a reva görüldüğü rolü yerine getirmektedir. Kırsal kesimden kopup gelen nüfusu kent merkezlerinde yerleşik işleri kabul etmeye zorlamanın yanında, bu yasalar aynı zamanda bir disiplin de yaratıyordu; bu disiplin sayesinde geleceğin proleterleri sanki kendi istekleri ve kaderleriymiş gibi ücretli emekçi olmayı kabul edecekti. Aynı şekilde, güvenlik toplumuna katılımımız da arzularımızın ve umutlarımızın ama en önemlisi de korkularımızın bir tür talim veya terbiyecisi olarak işlev görmektedir. Hapishane artık nüfusun deposudur bir bakıma ama aynı zamanda da "özgür” nüfus için korkutucu bir derstir de. Dahası, mevcut ekonomik ve finansal kriz başka korkular da doğurmaktadır. Ve birçok durumda en büyük korkulardan birisi işini kaybedip bu yüzden yaşamı sürdürme araçlarından yoksun kalma korkusudur. İyi işçi olmak, işverenine sadık olmak, greve gitmemek zorundasın; aksi halde işsiz kalır, borçlarını ödeyemezsin. Güvenlikleştirilen birey bir dizi ceza ve dış tehlike korkusuyla yaşar (Hardt ve Negri, 2012: 29-30). Korku ve kaygı, paradoksal olarak gönüllü gözetlenmeyi getirir. "Gözetim toplumu” bireyin özgürlügünü, güvenlik adına terk etmesine veya ertelemesine yol açmaktadır. Gözetim aracığıyla denetim, paranoid bir toplum yapısı üretmektedir (Bayhan, 2012:166).

4. Temsil Edilenler: Demokrasinin yozlaşması garip ve depolitize edilmiş temsil edilenler figürünü ortaya çıardı. Temsil aslında demokrasinin 
bir aracı olmayıp, tersine demokrasinin gerçekleşmesi yönünde bir engeldir. Temsil edilen figür, borçlandırılan, medyalaştırılan ve güvenlikleştirilen figürleri bir araya getirip, onların tabi konumda kalıp çürüdüklerini göstermektedir. Çok zengin olanlar siyaset yapmaktadır. Hükümette olduklarında, seçilmiş temsilciler zenginliklerine zenginlik katar. Ayrıca, eğer güçlü bir medyayı kontrol etmiyorsanız, politik olarak hangi hakikati dile getirebilirsiniz? Lobiler ve kapitalistlerin finanse ettiği kampanyalar bizi yöneten politik zümreleri göreve getirme ve gütme konusunda son derece etkilidir.

Güvenlik toplumunda yaşayanların korkusu, egemen medyanın korkutma taktikleriyle sinsice ve acımasızca üretilmektedir. Akşam haberlerini izlemeniz bile dışarıya çıkmaktan korkmanız için yeterlidir; süpermarket reyonları arasından kaçırılan çocuklardan terörist bombalama planlarına, komşu semtteki psikopat katillere kadar her şey vardır. Hobbes'in söylemiyle "Homo hominilupusest (İnsan insanın kurdudur). Politik hayatın aktif bir katılanı olmayan temsil edilen kendini yoksulluk içinde yoksul olarak bulmuştur. Bu toplumsal hayat vahşi ormanında tek başına korku içindedir. Dolayısıyla, temsil edilen, öteki figürler gibi; tıpkı medyalaştırılanların zekâsına, duygulanımsal kapasitelerine ve dilsel keşif güçlerine ihanet etmesi gibi; tıpkı korku ve teröre indirgenmiş bir dünyada yaşayan güvenlikleştirilenlerin çağrışımlı, adil ve sevgi dolu toplumsal mübadele imkânından yoksun bırakılması gibi, temsil edilen de etkili politik eyleme giremez. Çözüm, yoksullaştırılan ve içi boşaltılan öznel figürlere isyan etmekten geçiyor. Demokrasi ancak, onu kavrayıp hayata geçirmeye yetkin bir özne ortaya çıtığında gerçekleşecektir (Hardt ve Negri, 2012: 31-35). Chomsky’e göre, uzun zamandır seçimler, insanların dört yılda bir birtuşa basmak için heyecan duymaya çağrıldıkları, sonra da kendilerinden evlerine dönüp her şeyi unutmalarının istendiği halkla ilişkiler fantezilerinden ibarettir (Chomsky, 2013: 61). Ancak, demokrasi, salt çoğunluğun oyuyla iktidara gelen bir hükümeti içermez. Çoğunluğun oyuyla iktidara gelen eğer kendi tiranlığını kurup azınlıkların haklarını gasp ederse bu durum Karl Popper’in söylemiyle “demokrasi paradoksu”na dönüşür. Alain Touarine’nin tanımıyla demokrasi, azınlıkların haklarının da gözetildiği 
bir rejimdir. Demokrasi adına ne salt çoğunluk ne de salt azınlığın bir diğerine tahakküm kurması kabul edilemez. Demokrasiyi fetişleştirmeden temel sorunsal, birbirinin hakkına saygı duyup, empatik düşünebilen ve hoşgörülü birey yetiştirebilmedir. İktidarı elinde bulunduranların "devlet benim" yanılsamasıyla, devletin bütün kaynaklarını kendi yandaşlarına paylaştırması arkaik kültürün izdüşümüdür.

Demokrasi kültürü bireyin kimlik oluşumunda olgunlaştırılır. "Ağ Toplumu" kavramı ve teorisini geliştiren Castells, kimlik inşasının iktidarla ilişkilerine göre üç biçimde oluştuğunu belirtir: (Castells, 2006:14-16).

a. Meşrulaştırıcı Kimlik: Toplumun egemen kurumları tarafından, toplumsal aktörler karşısında egemenliklerini genişletmek ve akılcılaştırmak için inşa edilir. Otorite ve milliyetçilik kuramlarına uyan bir temadir.

b. Direniş Kimliği: Hâkim ve başat olanın mantığı tarafından değersiz görülen veya damgalanan konumlarda/koşullarda bulunan aktörler tarafından geliştirilir. Toplumun kurumlarına nüfuz eden ilkelerden farklı ya da bunlara karşı ilkeler temelinde direniş siperleri oluşturmak anlamına gelir. Direniş kimliği, komünlerin veya cemaatlerin yaratılmasını beraberinde getirir. Bu kimlik aynı zamanda, dışlayanların dışlananlar tarafından dışlanmasını ifade eder.

c. Proje Kimliği: Toplumsal aktörlerin, kendilerine sunulan kültürel malzeme temelinde toplumdaki konumlarını yeniden tanımlayan yeni bir kimlik inşa etmeleri; bunu yaparken bütün bir toplumsal yapıyı değiştirmeyi amaçladıkları kimlik türüdür.

Türkiye'nin sosyal tarihinde güncel ve yeni bir eylem olduğu için, gezi parkı eylemleri "direniş kimliği” bağlamında ele alındığında,yeni komün ve cemaat üretmesi bağlamında "biz" ve "öteki” ayrımlaşmasını ve çatışma riskini beraberinde getirir. Bu kimlik inşa türlerinden, birey olma ve özneleşme ancak proje kimliğiyle mümkün olabilir.

31 Mayıs 2013 tarihinde başlayan Taksim-Gezi Parkındaki eylemlere katılanların üç halkadan oluştuğu görülmektedir: 
1. Merkezde, ağaçlara sahip çıkarak olayları başlatanlar. Bireyci, mizahçı, bağlantısız ve politikanın yapılış biçimine ve icracılarına itiraz açısından “anti-politik" bir çekirdek. Desperados, Descamisados, İndignados adlarıyla anılmış/anılan alt sınıf protestocuların zıddı. Son 10 yılda artan refahın ve kentleşmenin ürünü olmak açısından, tipik diyalektik bir oluşum. Küçük bir akademisyen çekirdek tarafından kurulan “Taksim Platformu”nu da içeren bu halka "Geziciler" olarak kodlanabilir.

2. Onun etrafındaki ikinci halka epey heterojen. Çoğunun ortak noktası “AKP’ye karşıtlık” ve "ulusalcılık” olan örgütler, partiler. CHP 'liler, İP ve yan kuruluşları. Bayrak ve flamaları var. Platform'dan sonra kurulan ve Halkevleri örgütünün etkili olduğu 118 birimden oluşan “Taksim Dayanışması” tarafından harekete geçiriliyor.

3. Onun da etrafında üçüncü halka: Dünyanın her yerinde görülen "kırdökçüler". Şiddete başvurarak hareketi kirletenler (Oran, 2013). Bu halkadaki marjinal grup veya şiddet eğilimli terör örgütleri olarak betimlenenler, Taksim ve İstiklâl Caddesini terörize etmişler, kamu malları, kamu araçları ve işyerlerini yakıp yıkmışlardır. Eylemler polis müdahalesi ile bittikten sonra bile bu gruplar her fırsatta polisle çatışmayı sürdürmüşlerdir.

Çevre eylemi olarak başlayan gezi eylemleri, hükümetin istifasını isteyen ve devrim yapmak amacında olan bir duruma evrilmiştir. İstanbul'da Taksim ve İstiklal Caddesinin sokakları, Ankara'da Kızılay ve sokaklarında eylem yapanlar, yaya kaldırımları ve duvarlara bizzat başbakanı hedef alan küfürler ve hakaretlerle dolu yazılar yazmışlardır. Taksim'de darağacı gezdirerek başbakanı asacaklarını bağırmışlardır. Bu durum, yaptığı eylemi demokratik hak olarak tanımlayan, ancak diğer yandan demokratik seçimlerle işbaşına gelen hükümeti ve başbakanı şiddet kullanarak devrimle alaşağı etme zihniyetinin şizofrenik ve yabancılaşmış paradoksudur. Bu bağlamda, Taksim Gezi Parkı ile başlayan ve Türkiye'nin diğer illerinde devam eden eylemler, başbakanı hedef alan öfke ve nefretin dışa vurmasıdır. Eylemlerde Twitter'deaktivist bir sanatçının "Mesele sadece gezi parkı değil arkadaş, sen hala anlamadın mı?” söylemi iktidara karşı kalkışmanın bir göstergesiydi. 
Zaten eylemlerde direkt başbakanın hedef alınması ve hükümetin istifasının istenmesi, başbakan tarafından bu eylemlerin "faiz lobisi” ve Türkiye’nin kalkınmasını istemeyen dış ve iç güçler tarafından organize edildiği yorumunu getirmiştir.

Gerek Taksim Gezi Parkındaki eylemlerde, gerekse 2011 yılından beri Avrupa ülkeleri, ABD ve Arap Baharı eylemlerinde internet, sosyal paylaşım siteleri twitter ve facebook ile cep telefonları temel toplanma ve haberleşme araçları olarak kullanılmıştır. Postmodern toplumsal hareketlerin en belirleyici özelliği internetin yoğun ve etkin olarak kullanılmasidir.

Gezi Parkına polis müdahalesinin gerçekleştiği 31 Mayıs 2013 tarihinde, dakikada 3 bin tweet atıldı.Tweetlerin yüzde 88'i Türkçeydi ve yarısı İstanbul'dan gönderildi. Twitter'da şu başlıklar ön plana çıktı: “\#direngezi: 950 bin tweet, \#occupygezi: 170 bin tweet, \#geziparki: 50 bin tweet, \#BugünTelevizyonlarıKapat: 50 bin tweet (Radikal, 01.07.2013)". Twitter ve facebook kitlelerin anında toplanmasını ve yönlendirilmesini sağlamıştır. Ancak, twitter ve facebook'un provakasyon amaçli, olmayan şeylerin olmuş gibi yansıtılması ile halkın ajitasyonu bağlamında da kullanıldığı görülmüştür.

Dünyanın çeşitli yerlerindeki yeni toplumsal hareketler ile gezi parkı eylemleri arasında hem benzerlikler hem de farklılıklar bulunmaktadır. Küreselleşmenin toplumsal hareketleri ve isyanları bile aynılaştırması, isyanların bile küresel olarak pazarlanması sürecini üretmektedir.

Gezi parkı eylemleri yorumlanırken '68 Fransız başkaldırısını hatırlatanlar, Arap baharına gönderme yapanlar, occupywallstreet'i de kapsayan Avrupa "kızgınlar hareketi”ni kendine daha yakın bulanlar bulunmaktadır. Gezi meydan hareketi ise bunların hepsive hiçbiri. Hepsinden bir unsur taşıyor. Hepsi gibi sokağa çıkma, meydanı işgal etme, vatandaşın nöbet tutma hareketi. Ama hepsinden ayrılan bir özgünlüğü de mevcuttur.

Fransa 68 gençlik başkaldırı hareketi, uzun süren De Gaulle iktidarının yıpranması sonucu kıvılcımlanan, "yeter” sloganıyla gençliğin sokakları işgali ve polisle çatışması idi. Gezi meydan hareketi de, 68 
hareketi gibi, on yıllık iktidarın kişiselleşmesine "yeter" artık diyen bir başkaldırı hareketi olarak yorumlanabilir. Ancak, gezi hareketi gençliğin öncülüğünde oluştuysa da birçok farklı kesimden insanı, bürosundan, işinden, ticaretinden, evinden çıkıp gelen insanları birleştirdi, sıradan vatandaşları kendine çekmiştir.

Tahrir meydanının işgalinde simgeleşen Arap baharı, otoriter rejimlerin çözülmesine, demokrasi aracılığıyla çoğunluğun sesinin duyurulması talebine işaret ediyor iken; Türkiye' de ise, söz konusu olançoğunluk demokrasisinin eleştirisidir.

Batı kentlerini saran kızgınlar hareketine gelince, küresel neo liberal ekonomi karşısında ezilen yok sayılan insan haysiyetini dillendirmeleridir. Gezi işgal hareketi de liberalizmi eleştirmektedir. Ancak meydana çıkanlar ekonomik krizin mağdurları değil. Her şeyin ticarileştiği ekonomik büyüme canavarının piyonları olmak istemiyorlar.

Ağaçların yerlerinden sökülüp yerine AVM dikme projesi karşısında, gençler parkı işgal ederek yeni bir kentsel farkındalığı gündeme taşıdılar. Çevreci duyarlılık ve kapitalizm eleştirisi içiçe geçti. Genelde kapitalizm, küresel güçler, finans dünyası, neo-liberalizm gibi soyut kavramlar nedeniyle vatandaşın gündelik dünyasında yeterince somutluk kazanmaz iken; Türkiye'de ise kapitalizmin adı, AVM olarak somutlaşmaktadır.

AVM’ler, ticari kapitalizmin, tüketici toplumunun, küresel emek sömürüsünün cisimleşmiş hali olarak, kentsel gündelik yaşamın bir parçası oldular. İlk başta hevesle karşılanan, tüketim gözdesi olduğu kadar gezinti mekânları olan AVM'ler, giderek göze batmaktadır. Doyumsuz tüketiciliğin, rant ekonomisinin dinamikleriyle birleşerek kent dokusunu altüst etmeye başladılar. Gezi Parkı’nın ortasına AVM inşa edilmesi, İstanbullular gözünde kamusal alanın, vatandaşa açık mekânın özel sermayeler tarafindan istimlak edilmesinden başka bir şey değil. Gezi hareketi, kültür yerine tüketimi öne alan hiper kalkınmaya karş1 kentli yeni bir farkındalığa tercüman oldu (Göle, 2013a). Bu yorumlarından hareketle Göle, "yeni bir vatandaşlık" tipinin ortaya çıktığını savunmaktadır. Ancak, gezi parkı eylemlerindeki paradoks şuydu: Bir yandan çevreyi korumak ve dolayısıyla vahşi kapitalizmin tüketime 
endeksli felsefesini eleştirmek görüntü de olsa da; diğer yandan gezi parkı eylemcilerinin sosyolojik profiline bakıldığında nispeten üst sosyal sınıflardan gelen varsıl kesime mensup ailelerin çocukları olduğu görülmektedir. Ayrıca, bu eylemi destekleyenlerin bizatihi büyük sanayi ve ticari şirketleri olan kapitalistler olması, gezi parkı eylemlerinin ontolojik, epistemolojik ve etik çelişkisini oluşturmaktadır.

Zizek'e göre, küresel kapitalizm farklı ülkeleri farklı şekillerde etkileyen karmaşık bir süreçtir. Tüm çeşitliliklerine rağmen tüm protestoları birleştiren kapitalist küreselleşmenin farklı yönlerine karşı tepkileridir. Günümüz küresel kapitalizminin genel eğilimi, pazarı daha da genişletmek, kamusal mekanı çevreleyip kapatmaya yeltenmek, sağlık, eğitim, kültür gibi kamu hizmetlerinden kısmak ve giderek otoriterleşen bir siyasal iktidar sürdürmektir. Yunanlıların uluslararası finansal kapital ve temel sosyal hizmetleri sağlayamayan kendi bozuk ve verimsiz devlet yönetimine karşı protestoları bu nedendendir. Türkiyelilerin kamusal mekanın ticarileştirilmesini ve otoriter dinciliği protesto ediyor olmaları da bu bağlamda anlaşılmalıdır; Mısırlıların Batılı güçler tarafından desteklenen bir rejimi; İranlıların çürümüşlügü ve köktendinciliği protesto etmeleri bundandır. Dolayısıyla, tüm bu protestoların hiçbiri tek bir konuya indirgenemez (Zizek, 2013).

İçinde yaşadığımız post-modern gerçeklik, modernliğin kutsadığ mega söylemleringlobal ölçekte ciddî biçimde sorgulanmasına yol açmıştır. Böyle bir dünyadasiyasete bakış da farklılaşmıştır. Bu dünyanın önemli bir gerçekliği söz konusu söylemlerden nefret eden, ama bunumodernliğin siyaset kuralları çerçevesinde dile getirmeyen geniş bir kitlenin varlığıdır.

Ama taleplerini farklı ve modern siyasetinhoşuna gitmeyen yollarla dile getirmesi nedeniyle onun yok varsayılması da imkânsızdır. Bu belirli bir kalıba sokulması zorkitlenin talepleri, son tahlilde, siyasîdir; bu nedenle de siyaset tarafından gözardı edilemez.

Modernite ürünü, her türlü ihtiyaca cevap veren "medeniyet," "düzen" benzeri büyük söylemleri sorgulayan bu kitle,onlar bağlamında yapılan siyasetin doğanın dengesinden gıdaların kalitesine, savaşlardan 
iktisadî buhranlara ulaşanalanlardaki sorunların da yaratıcısı olduğuna inanmaktadır. Sosyal medyanın gelişimi, kendisini siyaset dışı gören bu kitlenindağınık enerjisini belirli hedefler üzerine yoğunlaştırabilmesini mümkün kılmıştır.Occupy Wall Street hareketinin sloganı olan "Biz \% 99'uz" iddiası belki abartılıdır. Ancak bu enerji Movimiento 15-M’inİspanya' da yaptığ 1 gibi büyük kitleleri sokağa dökebilmektedir. Bu kitle Türkiye'de de küçümsenemeyecek bir genişliğe ulaşmıştır (Hanioğlu, 2013a).

Taksim Gezi Parkı Olayları da tıpkı Wall Street eylemleri gibi, bir gençlik hareketi olarak başladı. Yine tıpkı Wall Street olayları gibi önceleri medya tarafından görmezden gelindi. Yine tıpkı Wall Street olaylarında olduğu gibi sert bir müdahaleye uğradı. Bu onun sempati kazanmasına ve diğer şehirlerde de yayılmasına yol açtı. Bir süre sonra medya hareket ile ilgilenmeye başladı. İşçi sendikaları, STK, bir kısım beyaz yakalılar ve nihâyet celebrity (ünlüler) dâhil oldu. Tepkiler de benzer gelişti. En sonunda hareket kendi savrulmasını yaşadı ve polis tarafından son bir hamleyle ezildi.

Süreçten içeriğe doğru gittikçe bu kez de farklılıklar dikkat çekici olarak görülüyor. Wall Street eylemleri daha fazla 'aşağıdakiler' ve 'kaybetmişlerin’ eylemi iken, Taksim Gezi bir beyaz yakalılar eylemi olarak başladı. Elbette ki her ikisi de bünyesinde çeşitli grupları barınd1rıyor. Ama tematik farklılıklar apaçı görülüyor. Wall Street eylemleri ile Taksim Gezi Parkı eylemleri arasındaki temel fark; ilkinin doğrudan kapitalizm karşıtllğ 1 ekseninde 'adâlet' sorununa vurgu yapması; ikincisinin ise 'yaşam tarzı özgürlüğü' ve 'çevre' meselelerini gündeme getirmesi. Bu taleplerden ilki doğrudan tüketim kapitalizmine desteği anlatıyor. Tüketim kapitalizminin değişmez parametresi zâten 'yaşam tarzlarının' nesneleştirilmesinden başka bir şey değildir. Öte yandan Taksim Gezi; Wall Street'ten farklı olarak sermâyeler arası bir savaşımın odağında gelişti. Wall Street eylemlerinde herhangi bir banka patronu görülmezken, Taksim Gezi eylemlerinde banka müdürleri isyanda taraf olmuştur. 
Parkta filizlenen 'light Paris Komünü' tecrübesi, en başta dokunulmazlık talepleri ile özgürleşme arasındaki bulanıklığı aşamadı. Öte yandan twitter'da 'hârikalar yaratan' zekâlar; Devrim Market açmak gibi zekâ yoksunu gösterilerde kendi kendisini tüketti. Nihâyet 'celebrity'nin olur olmaz müdahaleleriyle magazinel bir savrulmaya uğradı (Öğ̈un, 2013a).

68 hareketi, romantik, duygusal, şiirsel bir hareketti. 21. Yüzyılda ansızın mizah girdi hayatımıza. Gezi Parkı olayları sırasında insanlar birden bire mizahla karşılaştı 1968'in kendisi şiirdi. O kuşağın attığ 1 şu sloganlar şiir tadındadır: "Güzellik sokaktadır," "Gerçekçi ol, imkânsızı iste," "Mutluluğunuzu alıyorlar. Çalın onu," "Sıłıllmak karşı devrimciliktir," "Ne Tanrı ne efendi", "Yasaktır yasaklamak". İnsanlar şiir söylüyor, şiirle soluk alıp veriyordu.

Bu halin nedeni, çok açık bir biçimde romantisizmdi. 1968 gerçekçilikten falan dem vuruyordu, ama romantik, duygusal bir hareketti. Şiir, romantisizmdir. Ve her romantik yaklaşım kadercidir, Tanrısaldır. Her Tanrısal ve kaderci yaklaşım, trajiktir. Onu da yenilmek olgusundan veya gerçeğinden veya korkusundan koparmak olanaksızdır. Kazananların değil kaybedenlerin tarihidir ve öyküsüdür tragedya. 1970’lerde insanlar, çok inandıklarını sandıkları, ama dipten dibe belki de yeteri kadar inanmadıkları bir zihinsel/duygusal hareketin içindeydiler. Şiir bir kaçma, sığınma alanıydı. Şiir, yüzleşme değildir. Şiiri herkes yapamaz. Şiir, şairin yani bir tür Şaman’ın, sağaltıcının, efendinin işidir. İnsanlara onu izlemek düşer.

21. yüzyılda bu anlayış değişti. Çünkü insanların şiirle uğraşmayı gerektiren o romantik ve depresif duygusu, artık söz konusu değil. Narsisizm çağında, insanların 140 karakterle kendilerini diledikleri gibi ifade ettikleri, herkesin 15 dakika şöhret olma imkânına sahip olduğu bir dönemde, şiirin duygusallığına kimsenin ihtiyacı kalmadı. İnsanların artık efendileri yok. Kendileri kendilerine efendi oluyor, bu da yetiyor. $\mathrm{Bu}$ şartları reklamcılık dünyası hazırladı. Reklamcılığın dili, sloganın dilidir. Tweet, slogandır. Her slogan, saldırır, yıkar ve çürütür. İnternet şimdi herkesi reklam yazarı haline getirdi. Fakat internet ortamı, sadece 
sınırsızlık değil, aynı zamanda özgürlük ve sahipsizlik alanıdır. İnternet dünyasında kimsenin kimseden korkusu yok, olamaz da. Hele o sanal dünyada hiçbir şeyin gizli kalmadığını, hiçbir şeyin mahrem olmad1ğını, hiçbir şeyin dokunulmazlığının bulunmadığını düşününce Gezi’nin çıtı̆̆ğ gezi daha iyi anlaşılıyor (Kahraman, 2013).

Gezi parkı eylemleri, siyasal hareketlerden farklı olarak, doğaçlamaya, mizaha, yaratıcılığa açık bir hareket. Nitekim gençler 60 'lı yılların barış ve karşı kültür hareketlerinin amblemi Woodstockrockfestivalini hatırlatırcasına, müzik, ekoloji, politika, çiçek, bira ile birlikte bir tür komün yaşamını meydanda tecrübe ediyorlar.

Bugünün küreselleşen iletişim ağları, sosyal medya, facebook, twitter aracılığıyla sahneye koydukları, doğaçladıkları alternatif barışçıl meydan kültürünü an be an, eşzamanlı bir biçimde dünya seyircileriyle paylaşıyorlar. Ayyaş ve çapulcu kelimeleri mizah süzgecinden geçirildi, evrildi çevrildi, İngilizce deyimlerle karıştırıldı, farklı medyalar, kişiler bu oyuna dahil oldu, kelimelere yeni manalar yüklendi. Tüm başkaldıranlar kendilerini ayyaş özellikle de çapulcu olarak takdim ederek, rencide eden, yaralayan sözleri tersyüz ettiler; bu da hareketin ortak kimliğini oluşturdu (Göle, 2013a).

Gezi parkı eylemlerinde futbol taraftarları ve özellikle Beşiktaş Futbol Kulübünün taraftar örgütü olan "Çarş”” etkin konumda yer almıştır. Çarşı, Beşiktaş semtinin çarşısında, bir esnaf grubunun da desteğini alarak doğdu. Ama kendi kültürlenmesi içinde bu kurucu bağ 1 çok aştı. İçerdiği ve başlarda herkesin sempatisini kazanan anarşizan ruh, onu nihâyet siyasete taşıdı. Gezi olaylarında 'çarşı' kendisine baskın bir yer edindi. Bu hâli onu kimilerinin gözünde daha da sevimli kılarken; kimilerinin gözünde de alabildiğine sevimsizleștirdi. Ama en tuhaf olanı; uzadıkça uzayan eylemlerin özellikle Taksim ve Beyoğlu'ndaki turizmi bitme noktasına getirmesi ve geçimini turistik hareketlerden sağlayan 'gerçek çarşıyı' çileden çıkartması oldu. Ödenecek senetler, kiralar ve personel ücretlerinin derdine düşen esnaf yavaş yavaş ortaya çıkmaya, elinde palası, döner bıçağı, sopa ve ateşli silâhlarıyla eylemcileri hedef almaya başladı. Elbette ki bu gelişmeler hiç de hoş ve hukuk 
devleti itibarıyla kabul edilebilir değil. Ancak, ödenmemiş senet ya da kira, 'yaşam tarzlarını korunması' talebinden çok daha somut bir önceliktir. Bu bağlamda,'Çarşı her şeye karşı' ama bu kez 'Çarşı Çarşı̀ya karşı' (Öğün, 2013b).

Postmodern toplumsal hareketlerin, örgütlenişi, ortaya çıkışı ve sürecinin birbirine benzemesinden mülhem belli güçler tarafından kurgulandığ 1 ifade edilmektedir.

Almanya’nın uluslararası yayın kuruluşu DeutscheWelle, hazırladığı programda Mısır devrimiyle başlayan Arap BaharındaOtpor'un izini sürüyor. Mısır'da Hüsnü Mübarek'i deviren göstericilerin taşıdığı bayraklarda siyah zemin üzerinde sıkılmış bir yumruk göze çarpıyor. Söz konusu sembol Sirp internet aktivistleriOtpor üyelerinin sembolüydü ve bu sembolü taşıyanlar da onlarla işbirliği içindeydi. Slobodan Miloseviç rejimi sırasında bir grup öğrenci tarafından kurulan ve daha sonra CIA ve George Soros tarafından kendi çıkarlarına hizmet için kullanılan bir örgüt. Otpor, Sırpça-Hırvatçada "direniş" anlamına gelmekte.

DW'ye konuşan OtporaktivistiMaroviç, bir rejimi yıkmak için ilk etapta kara mizah, ardından da sokaklarda gösteri yapmanın gerekli olduğunu belirtiyor. "Rejimin komik yanlarını gösterirsiniz ve sonrasında onun meşruiyetini kaybettiğini söylersiniz. Sonrasında da neler yapılması gerektiği konusunda çalışmaya başlarsınız." diyen Otporaktivisti daha sonra nasıl uluslararası bir dijital devrim ihraç malzemesine dönüştüğünü aktarıyor.

Maroviç, Otpor'un daha sonra CANVAS (Uygulamalı Şiddet İçermeyen Eylem ve Stratejiler Merkezi) şekline dönüştüğünü ve dünyanın diğer bölgelerindeki benzerleriyle internet üzerinden irtibat kurduklarını ve onlara akıl hocalığı yaptıklarını belirtiyor.Ukrayna'da yapılan 'turuncu devrim', Gürcistan'daki 'gül devrimi', Kırgızistan'daki 'lale devrimi', Beyaz Rusya' daki 'kot devrimi’ndeOtpor'un nasıl etkili olduğu da programda anlat1liyor (GazeteA24.com, 19.06.2013).

Bu bağlamda, Taksim Gezi Parkı’nda yol genişletme çalışması sırasında sökülen ağaçlara tepki olarak başlayan daha sonra da dalga dalga yayılan eylemler, alanlardaki kitle tarafindan, "demokratik bir tepki " 
olarak algılansa da eylem sırasında kullanılan sosyal medya yöntemi, sonrasında yaşananlar ve özellikle de dış medyanın abartılı yaklaşımların teorik yazarı 2009 Nobel Barış Ödülü’ne de aday gösterilen Amerikalı sosyolog ve siyaset bilimci Gene Sharp'tır. 'Diktatörlükten Demokrasiye' (FromDictatorshiptoDemocracy) adlı kitabı, dünyanın hemen her yerinde şiddet içermeyen devrim aktivistlerinin el kitabıdır. Sırbistan'da SlobodanMiloşeviç ve Ukrayna' da ViktorYanukoviç’i düşüren demokratik hareketler de Sharp'tan ilham aldıklarını ifade etmiştir.Sharp’ın temel yaklaşımı basit devrim mantığıdır; "Diktatörler, kendilerine itaat edildiği için iktidarda kalır. Onlardan korkulmaz ve itaat edilmezse zorda kalırlar”. Sharp’ın sivil itaatsizlik başlı̆̆ı adı altında topladığ “ "198 eylem"inbir çoğu Gezi Parkı’nda da sahnelenmiştir. Sharp’a göre, sanatç1lar, öğrenciler, sıradan vatandaşlar, parklarda, toplu taşıma araçlarında, kamu binalarında çeşitli eylemler sergilemeli. Duvar yazıları, maskeler, şiirler, tek tip kıyafet giyme, toplu oturma olarak uygulanan gösterilerde, eylemciler, birbirleriyle yakın ilişki içinde olmalı tabi en önemlisi ise fikir birliğinin olmasıdır (Gençer, 2013).

İngilizce'de işgal etmek anlamına gelen “Occupy” ilk kez 2011'de Wall Street'teki eylemler için kullanılan bir simge oldu. "Occupy” Gezi Parkı eylemlerinde de başından beri süreci yönlendiren portallardan biri oldu. İlk başta "DirenAnadolu” olarak devreye sokulan uzantı, eylemler başladığında da \#DirenGeziParkı etiketiyle en etkili mecralardan biri haline geldi. Sayfanın devreye sokulduğu tarih de oldukça önemli. Aralık 2012' de kurulduğunda "DirenAnadolu” bağlantı adını seçerken, "livestream" adlı video yayın sitesindeki hesaplarının adı da "revoltistanbul"du. "Revolt" İngilizce "ayaklan" veya "diren" demek. Occupy ve revolt, gezi parkındaki eylemlerde sağa sola yazılan yazılarda, pankart ve afişlerde sıkça kullanılan bir ifadeydi. Öyle ki, popüler kültürü kullanan kapitalizm, 'occupygezi' ifadesini t-shirtlere bastırıp İstanbul Kapalıçarşı' da satışa sundu hemen.

İster hükümetin bireyin yaşam tarzına müdahale etmesi algısı gerekçe gösterilerek başlatılmış olsun, isterse güdümlü ve organize edilmiş hükümeti düşürme operasyonu olsun gezi parkı ve sonunda meydana 
gelen olaylar, toplumda "kılıçlarını kınında tutan" kültürel ayrımlaşmanın daha da keskinleşmesine neden olmuştur.

Hanioğlu'na göre, Soğuk Savaş sonrası dünyasında yirminci asrın ideolojik çatışmaları ile "sınıf mücadelesi" gibi,kültürel unsurları arka plana iten kavramsallaştırmaların düşüşe geçtiği tartışılmaz bir gerçektir.Global dönüşüm, tarihî köklere dayanan ve gerçekte önemini hiçbir zaman kaybetmemiş bir çatışmayı yeniden siyasetintemel ekseni haline getirmiş, "yaşam tarzı," ideolojilerin önüne geçmiştir.

Toplumumuzdaki "kalkınmacı muhafazakârlık" ve "devletçi modernleşmecilik" kutuplarının günümüzde”pazar, üretim, rekabet şartları, emek, çalışma koşulları, sosyal güvenlik" benzeri konuları ikinci plana atankültürel çatışma ve yaşam tarzı tartışması üzerinde yoğunlaşmaları tesadüfî değildir.

Kültürel çatışma merkezli ve yaşam tarzı vurgulu siyasetin yakın dönemde değişmesini beklemek gerçekçi değildir. Dolayısıyla böylesi bir beklenti içine girmek yerine bu siyasetin çatışmacı karakterinin törpülenmesi yolunda adımlaratılmalıdır.Bu alanda atılacak ilk adım şüphesiz, demokrasilerde kültürel farklılıkların ve değişik yaşam tarzlarının doğal olduğunun toplumun genelince kabul edilmesini sağlamaktır. Uzun süre toplum mühendisliği uygulamasına maruz kalmış, siyasetinbelirli niteliklere sahip "nesil" yetiştirmeyi en önemli vazifelerden birisi olarak gördüğü, "gençlik" kavramsallaştırmasınıntek tip bireylerden oluşan bir kitleye vurgu yaptığı bir toplumda bunun ne denli zor olacağ ortadadır.İttihadçılı̆̆ın başlattığı, Erken Cumhuriyet liderlerinin zirveye ulaştırdığı toplum mühendisliği projelerinin"Cumhuriyet kadını" benzeri ideal tipler üzerinden "tektipleştirmeyi” gerçekleştirmeye çal1şan, uyumsağlayamayanları "Ötekileştiren" niteliği, kültür temelli siyaset yapımının çatışmacı karakterini güçlendirmiştir.

Yeniden ve artan bir ivme ile yöneldiğimiz kültür çatışması siyasetinin kapsamlı toplumsal huzursuzluklara neden olmasınıönlemenin yolu demokratikleşme aracılığıyla farklılıkların güvence altına alınmasıdır. Bu, kültür(ler) arası mücadele vesiyasetin bu temelde üretilmesini önleyemez; ancak onun toplumsal çatışmaya dönüşmesine engel olur. 
Mesele, tüm bireyleri ahlâk anlayışımız ve dünya görüşümüz çerçevesinde tektipleştirerek, "ideal" bireylerden oluşan, bukıstaslara uymayanların ötekileştirileceği bir toplum ve "gençlik" yaratmak değil; Gezi Parkı’nda gitar çalan küpeli Ahmetile Üç Aylar'da kıldığı nafile namazın sayısını artıran Mehmet, başörtüsüyle üniversitesine devam eden Ayşe ilemuhafazakârlığı kadınlığa müdahale olarak gören Fatma’nın birarada yaşamasını sağlamaktır (Hanioğlu, 2013b).Ancak, bunu sağlayabilmek kolay görünmemektedir. Gezi Parkı eylemlerinde ortaya ç1kan kültürler arası çatışmada "ya bizdensin" ya da "onlardan" psikolojisi keskinleşmiştir.

Bu bağlamda, Gezi Parkı olaylarını tasvip etmek "demokratik bir tutum" veya "demokrasi mücadelesi"; kınamak ise "iktidar yandaşlı̆̆ı" gibi dar bir kıskaca alınmış, dolayısıyla toz-duman içinde adeta bir kör döğüşü başlamıştır. Sarıbay (2014), bu kavganın postmodern kültüre içkin olan narsisizm ile ilgili olduğunu ifade eder. Sosyolog Christopher Laschçok ünlü eseri Narsisizm Kültürü’nde, 20. Yüzyılın (21. Yüzyılda da devam eden) önemli sosyolojik hususiyetinin "iktisadi insan"1n yerini, burjuva bireyciliğinin en son ürünü olan "psikolojik insan”a bıraktığını vurgular. Lasch’a göre, bu insan tipi, toplumun her alanındaki “otoriterliği” sorgulayarak, "otoriter kişiliğin” kapitalizmin temelini oluşturan iktisadi insanın özgün bir tipi olmadığına dair bir başkaldırıyı temsil etmektedir. O kadar ki, bu otorite karşıtllı̆̆, ister istemez narsist bir kişilik yapısını (gerçekle bağıntısını dikkate almadan daima kendini haklı görmek) yaygınlaştırmakta; eleştirdiği ve çökmesini mukadder gördükleri bir sistemin, düzenin neticede bir "kültürel devrimi” zorunlu kıldığını addetmektedir.

Şüphesiz, böyle bir kişilik tipinin taşıdığı hissiyat, aslında içine gömülü olduğumuz günümüz kültürel durumundan bağımsız değildir. Bu postmodern kültürel durum, herkesin kendi gerçeğinin geçerli olduğu bir özelliği içeriyor: Bugüne kadar bir arada düşünülemeyecek şeyleri insanlar, "ben yaptım oldu" diyerek mubah hale getirmenin ve bunu "kendi gerçeği” olarak sunmanın (birçok durumda dayatmanın) sözde meşruluğunu bu tür kültürden alıyorlar; kendini bazen narsisizm, bazen 
de egoizm şeklinde göstererek. Narsisizm ve egoizm arasında salınımın mukadder sonucu ise yalnızlaşmadır (Sarıbay, 2013).

Gezi Parkı Olaylarına bakıldığında; “demokrasi” yaftası altında geçmişin, demokrasiyle en bağdaşık olmayan özellikleri üzerinden tedavüle sokulduğunu gördüğümüz kadar; çevredeki çöpleri poşetlere doldurma, "nezaketi”ne ve akranlarına ve (sosyal) medyaya bakılarak tekrarlanan paketlenmiş duygular gösterimine ve nihayet grup kimliklerinin atomik parçalanmasına da tanık oluruz. Nezaketin, süregiden bir öfke patlamasına dönüşmesi ise esasen sosyolojik olarak anomiye tekabül eden bir olay mahiyetindedir.

Anomi, yaygın kullanımı ile "kuralsızlı" olarak tanımlansa da, Durkheim'inanomi'yi tanımlarken kullandığı Fransızca "Dereglement" sözcügüu, çllgınlık/delilik durumunu ifade eder. Bu anlamda anomi, her tür verili kurala aykırı irrasyonel davranışa tekabül eder. Durkheim, bu anlamda anomi'nin "iradenin/istencin tiranisi” şeklinde kendini açığa vurarak egoizmi kışkırtabileceğine; öte yandan "dipsiz arzuların” (ki çağımızın da en belirgin özelliği) tatmin edilememesinden doğan acı çekmeyi artırabileceğine işaret etmiştir. Fakat bu döngüsel bir şekilde gelişir: Arzular/istekler ne kadar şiddetliyse, istencin tiranisi o kadar mütehakkim şekilde ortaya çıkar ve arzuların tatmini ihtiyacını artırarak egoizmi kışkırtır; egoizm kışkırtıldıkça istencin tiranisi genişler ve pekişir. Bunun anlamı, arzularımızın bihakkın tatmin olamayacağıdır. Demokrasinin hem imkânı, hem paradoksu da bu noktaya münhasır olarak ortaya çıkar: Modern öncesi toplumlarda insanlar kanaatkâr şekilde toplumlarının arzu etmelerine imkân verdiği oranda arzu ederlerdi. Fakat modern insan, o kadar çok ihtiyaç, nesne ve seçenekle karşı karşıyadır ki; bunların bihakkın karşılanamaması, insanda son tahlilde hayal kırıklığına dayanan bir öfkeye dönüşme potansiyeli de gösterir. Öfke, kalabalık halinde vuku bulduğunda; insanın bireysel ahlaki sorumluluktan kurtulma yolu açllır ve o yolda ilerledikçe de birey kendisini sosyal çevrenin aciz bir kurbanı şeklinde tanımlayan ideolojik bir kılıfa bürünür: Tarihsel olarak birçok radikal eylemin göstermiş olduğu gibi, söz konusu ideolojik kılıf rengini nostaljik şekilde altın çağ misali bir geçmişten alır. Böylece, tatmin edilmediği düşünülen toplumsal, ekonomik ve siyasal arzular kitleselleşir ve sırf bu kitlesel özellik 
yüzünden eylemler, demokratikleşmetalebi şeklinde ifade bulur. Oysa, kitleselleşme, sosyolojik bir homojenleşmenin eşliğinde sanal bir eşitliği gerçekmiş duygusuyla kurgular; kalabalıktaki çeşitlilik, demokratik siyasal bir farklılık gibi algılanarak kimliksizleşmeninüstünü örter. Birey kendisini kalabalıkla özdeş görmeye devam ettiğinden herkes kalabalığın istencini ve bunun doğurduğu tiraniyi (despotluğu), kendi istenci ve tiranisi (despotluğu) gibi görür; görmeye devam ettikçe de kalabalıkla özdeşleşir. Bu anlamda bireysel yalnızlığı kalabalık telâfi ederken, ironik olarak, kalabalığın kendisi de yalnızlaşır (Sarıbay, 2013). Biz ötekini üretir. Taraf olmak bir bakımdan rahatlık sağlarken, diğer yandan diğerine göre öteki olduğu için sürekli savunma ve kaygıyı da beraberinde getirir.

\section{Sonuç}

Gezi parkı eylemleri bağlamında yeni veya postmodern toplumsal hareketler, zımni olan "kültür çatışması”nın dışa vurumudur. Birbirini ötekileştiren "laik ve İslamc1, Alevi ve Sünni, Türk ve Kürt” vb. kitlelerin zemin bulduklarında "kültürel haçlı seferlerini” başlatmaları gecikmemektedir.Küreselleşme bağlamında 11 Eylül eylemleriyle ortaya ç1kan "İslamofobia", nasıl Batı ile Doğu ülkeleri arasında çatışmanın ve “ötekileştirmenin” temeli olarak sürüyorsa; Türkiye'de de "islamofobia” Türkiye'nin geçirdiği kültürel değişim sürecinde laik ve İslamcılar arasındaki ayrımlaşmada başat rol oynamaktadır. İktidara gelen, kendini muhafazakâr demokrat olarak tanımlayan ve liberal ekonomi-politika uygulayan AKP'nin "İslam temelli muhafazakâr yaşam tarzını" tüm topluma teşmil edeceği "korkusunu” taşıyan laikler ile kendilerini muhafazakâr olarak tanımlayanların önceki iktidarlarca kendi yaşam tarzlarına müdahale edildiği kabulü ve korkusu "paranoid-şizoid toplum” oluşmasına neden olmaktadır. Kuşkucu ve içe kapanan toplumsal ruh hali, farklı yaşam tarzına sahip kitlelerin dışa kapalı gettolar oluşturmasına ve kültürel çatışma riskini üretmektedir. Bu durum, küresel bağlamda "Batı" ile "Doğu" toplumları ve ülkeleri arasında yaşanırken, Türkiye içinde de çoğu kere deneyimlediğimiz gibi caridir. 
Nasıl ki, Avrupa ülkeleri ve ABD’deki 68 gençlik eylemleri, 1968 y1lında Türkiye'de taklit edilmişse, Gezi Parkı eylemleri de 2011 yılında ABD, İngiltere, İspanya, Yunanistan'da yaşanan ve Arap Baharı eylemleri gibi taklit edilmiştir. 1968 gençlik eylemleri gibi 2013 Gezi parkı eylemleri de romantiktir. Küresel olarak pazarlanma boyutu ihtimali ile Türkiye'nin toplumsal ve kültürel bağlamının kolajıdır. Avrupa ve ABD'de 1968'de yaşanan gençlik eylemleri olup-bitmişken, Türkiye' de 1968'de başlayan gençlik eylemleri 70'li yıllar boyunca terör ve şiddet eylemleri şeklinde sağ-sol çatışmasına dönüşmüş ve kardeşin kardeşi öldürdüğü, toplumun polarize olduğu anomik ve anarşik yapıya evrilmiştir. Sonuç 1980 askeri darbesidir. Toplumsal ve kültürel bağlamda zımni olan çatışmanın geçmiş kötü deneyime dönüşmemesi için hepimizin sağduyuya ve objektif sosyolojik analize ihtiyacımız vardır. Sosyoloji hayatın içinden söz söyler ve hayatı yansıtır. Sokrates'in "Kendini Bil" mottosu ve Yunus Emre’nin "İlim ilim bilmektir / İlim kendin bilmektir / Sen kendini bilmez isen / Ya nice okumaktır" dizelerinde anlam bulan habitusu bize sosyoloji sağlar. 


\section{Kaynakça}

Alpuncu, Baran (2013): “Gezi Parkını Nasıl Okumalı?”, Radikal Kitap, 07.06.2013.

Bayhan, Vehbi (2012): “İngiliz Baharı mı? Ağustos 2011'de İngiltere’de Yaşanan Ayaklanmaların Sosyolojik Nedenleri”, Sosyoloji Konferansları, Sayı:46, İstanbul Üniversitesi İktisat Fakültesi Yayını, İstanbul.

Bayhan, Vehbi (1997): Üniversite Gençlĭginde Anomi ve Yabancılaşma, Kültür Bakanlığı Yayınları, Ankara

Castells, Manuel (2006): Enformasyon Çağl: Ekonomi, Toplum ve Kültür, 2.Cilt Kimliğin Gücü, (Çeviren: Ebru Kılıç), İstanbul Bilgi Üniversitesi Yayınları, İstanbul.

Chomsky, Noam (2013): Occupy / İşgal Et, (Çevriren: Osman Akınhay), Agora Kitaplığı, İstanbul.

Çayır, Kenan (1999) :"Toplumsal Sahnenin Yeni Aktörleri: Yeni Sosyal Hareketler",

(Derleyen: Kenan Çayır), Yeni Sosyal Hareketler, Teorik Açılımlar, Kaknüs Yayınları, İstanbul, 1999.

Çopuroğlu Y. Cemalettin ve Beyzade Nadir Çetin (2010): "Yeni Sosyal Hareketler Paradigması Bağlamında Türkiye'deki Küreselleşme Karşıtı Grupların Birbirleriyle ve Dünyadaki Karşıtlarla Karşılaştırılması", Sosyoloji Araştırmaları Dergisi, Cilt: 13 Sayı: 1, Bahar, Ankara.

GazeteA24.com, 19.06.2013, http://www.gazetea24.com/haber/duran-adam-otpora-mi-calisiyor-otpor-nedir-otpor-belgeseli-izle_23472622. html.

Gençer, Okan (2013): "198 Pasif Direniş Yöntemi ve Gene Sharp", 15-06-2013, http:// www.yazete.com/genc-kalemler/okan-gencer/198-pasif-direnis-yontemi/2301/ 
Göle, Nilüfer (2013): "Yer Sofrası ve Sınır İhlalleri”, T24, 15-07-2013, http://t24.com.tr/yazi/yer-sofrasi-ve-sinir-ihlalleri/7056

Göle, Nilüfer (2013a): “Gezi: Bir Kamusal Meydan Hareketinin Anatomisi”, T24, 06-06-2013, http://t24.com.tr/yazi/gezi-bir-kamusal-meydan-hareketinin-anatomisi/6824

Gürakar, Tolga (2014): "Bir Direniş Oyunu: Gezi'yi Bourdieu Üzerinden Okumak”, Sosyologca, Say1:7, Ocak- Haziran 2014, İstanbul.

Hanioğlu, Şükrü (2013a): "Siyaset Nefretinin Siyasallaşması”, Sabah Gazetesi, 09 Haziran 2013.

Hanioğlu, Şükrü (2013b): "Siyaset ve Kültürel Çatışma”, Sabah Gazetesi, 07 Temmuz 2013.

Hardt, Michael \&Negri, Antonio (2012): Duyuru, (Çev: Abdullah Yılmaz), Ayrıntı Yayınları, İstanbul.

Işık, Gülcan (2013): “Yeni Toplumsal Hareketler ve Sanal Gerçeklik Boyutunda Gezi Parkı Eylemleri”, Selçuk İletişim, Journal Of SelcukCommunication, Selçuk Üniversitesi İletişim Fakültesi Akademik Dergisi Cilt 8, Sayı 1, Temmuz 2013, Konya.

Kahraman, Hasan Bülent (2013): “Mizah mı Şiir mi?”, Sabah Gazetesi, 14 Temmuz 2013.

Macionis, John J. (2012): Sosyoloji, (Çeviri editörü: Vildan Akan), Nobel Yayınları, Ankara.

Melucci, Alberto(1999): "Çağdaş Hareketlerin Sembolik Meydan Okuması”, (Der: Kenan Çayır), Yeni Sosyal Hareketler, Teorik Açılımlar, Kaknüs Yayınları, İstanbul.

Oran, Baskın (2013): “Taksim-Gezi’nin Üç Halkası ve AKP”, Radikal İki, 14-07-2013.

Öğün, Süleyman Seyfi (2013a): “Daha İyi Bir Dünya ve Taksim-Gezi...”, Yeni Şafak Gazetesi, 13-06-2013.

Öğün, Süleyman Seyfi (2013b): “Çarşı Çarşıya Karşı...”, Yeni Şafak Gazetesi, 15-07-2013. 
Sarıbay, Ali Yaşar (2013): “Demokrasinin Yalnız Kalabalıkları”, \#Diren Sosyoloji, (Editör: Ekrem Saltık), Kaldırım Yayınları, İstanbul.

Stein, JoelandJoshSanburn (2013): “The New Greatest Generation”, Time , 5/20/2013, Vol. 181 Issue 19, p26-33.

Şentürk, Ünal (2006) : "Küresel Yeni Sosyal Hareketler ve Savaş Karşıtlığı”, Cumhuriyet Üniversitesi Sosyal Bilimler Dergisi, Mayıs 2006,Cilt : 30, No:1 31-46.

Touraine, Alain(1999): “Toplumdan Toplumsal Harekete”, (Der: Kenan Çayır), Yeni Sosyal Hareketler, Teorik Açılımlar, Kaknüs Yayınları, İstanbul.

Türköne, Mümtaz’er (2013): "Yeni Toplumsal Hareketler”, Zaman Gazetesi, 09 Ağustos 2013.

Uysal, Ahmet (2013): “Teori ve Pratik Arasında Gezi Protestoları, Bir Toplumsal Hareket midir?”, ”, \#Diren Sosyoloji, (Editör: Ekrem Saltık), Kaldırım Yayınları, İstanbul.

Zizek, Slavoj (2013): “Cennette Sıkıntı”, Radikal Gazetesi, 26-06-2013.

Abstract: -New Social Movements and Gezi Park Resistance- The economic crisis which the global neoliberalism has faced leads to new social movements. The protests in the USA, the UK, Spain, Greece, the revolts called Arab Spring and the İstanbul Taksim Gezi Park Resistance that took place in 2013 some of the examples of the new social movements. The essence of the new social movements is actually a demand for social and cultural identities. Taksim Gezi Park resistance first started as an environmentalist activity to prevent the authorities to cut the trees in the park and build a mall there. However it turned out to be a revolutionary movement in which all the legal and illegal groups came together who werea against the government and forced them to resign. There volts started in İstanbul spread to most of the other cities of Turkey. Gezi Park resistance which started as an innocent 
movement was terrorized by means of act of force. Gezi Park protests can be analysed as follows: 1 . The youngs who were labeled as apolitical after the 1980 coup were blessed and praised for the irroles in Gezi Park protests as a ' $\mathrm{Y}$ generation'. 11 . The protests have been considered as an objection to the government for its 11 year of development based neoliberal policy. 111. The protests turned out to target Prime Minister who had been in the office for 11 years and over throw the government. $v$. The Prime Minister analysed the protests as a conspiracy theory in which the external and internal powers who didn't want Turkey to develop organised together. $v$. The socialists called the Gezi Park protests as "Taksim Commune" and they were excited. $v$. Social media and Internet were the basic pulpits during the Gezi Park protests just like in the Arab Spring revolts. Like the youth movements that took place in 1968, Gezi Park resistance in 2013 June was the imitation of the social movements in the other countries. Both the 68 protests and the 2013 Gezi Park resistance were romantic. In this context, there volt is contagious. But although the Gezi Park resistance was romantic, it reflected the hatred of the people who were against the government and couldn't overthrow it by elections. This unearthed the differentiation of "we" and "other" that exists in society. This produces a "Paranoid-Schizoid Society" structure in which no body thrust the other people and approach them with suspicion.

Key words: New social movements, Gezi Park resistance, The crisis of neoliberalism, Paranoid-schizoid society. 
